\title{
Tree Leaves as Bioindicator of Heavy Metal Pollution in Mechanic Village, Ogun State.
}

\section{*OJEKUNLE ZO ${ }^{1}$., ADEBOJE M $^{1}$, TAIWO AG ${ }^{2}$, SANGOWUSI RO ${ }^{1}$, TAIWO AM ${ }^{1}$ OJEKUNLE VO V $^{3}$}

\author{
${ }^{1}$ Federal University of Agriculture, Abeokuta, Ogun State. Nigeria \\ ${ }^{2}$ Moshood Abiola Polytechnic, Abeokuta, Ogun State. Nigeria \\ ${ }^{3}$ Chinese Academic of Sciences CAS-TWAS, Institutes of Rock Sciences, Wuhan. China \\ Corresponding AuthorE-Mail:taiwoademat2008@yahoo.com,oojekunle@yahoo.com
}

\begin{abstract}
Metal contamination issues are becoming increasingly common in automobile workshop and elsewhere, Heavy metals, such as cadmium, copper, lead, are major environmental pollutants. Heavy metal accumulation in soils is of concern in agricultural production due to the adverse effects on food safety and marketability, crop growth due to phytotoxicity, and environmental health of soil organisms. Soil and plant samples were collected from mechanic village in Odeda local Government of Ogun State. The soil samples were collect at depth of 0$15 \mathrm{~cm}$ and $15-30 \mathrm{~cm}$, which are top soil and sub soil. The physiochemical parameters for soil were determined through the standard method and the heavy metal concentrations were determined using AAS. (Atomic Absorption Spectrometer). The EC range of the control farmland is 25 $\mu \mathrm{S} / \mathrm{cm}-195 \mu \mathrm{S} / \mathrm{cm}$ at $25^{\circ} \mathrm{C}$ while that of mechanic village ranges from $70 \mu \mathrm{S} / \mathrm{cm}-276 \mu \mathrm{S} / \mathrm{cm}$ at $25^{\circ} \mathrm{C}$, the temperature of the farmland ranges from $27.8^{\circ} \mathrm{C}-28.0^{\circ} \mathrm{C}$ while that of the mechanic village ranges from $27.7^{\circ} \mathbf{C}-28.1^{\circ} \mathbf{C}$. The $\mathrm{pH}$ of the farmland and mechanic village ranges from 6.47-7.67 and 6.48-7.79 respectively. The mean concentrations of the heavy metals in the soil of the farmland are in order of magnitude $\mathrm{Cd}>\mathrm{Cu}>\mathrm{Pb},(0.62>0.018>0)$ while the mean concentration of the heavy metals in the soil of the mechanic village are in order of magnitude $\mathrm{Pb}>\mathrm{Cu}>\mathrm{Cd}$ $(2.96>0.67>0.14)$ The mean concentration in leaf of farmland are $\mathrm{Cu}>\mathrm{Cd}>\mathrm{Pb}$. $(0.105>0.03>0.0001)$, while the mean concentration in mechanic village are $\mathrm{Cu}>\mathrm{Pb}>\mathrm{Cd}$. $(0.13>0.11>0.02)$ the sudden rise of lead in mechanic village is understandable giving the various activities such as painting, welding, soldering and fueling which contain lead. Though the result indicate that they are not significant as they that are within the acceptable standard of FAO and WHO, 2010. ( JASEM
\end{abstract}

http://dx.doi.org/10.4314/jasem.v18i4.12

KEYWORDS: Bioindicator, Contamination, Environmental Health, Heavy Metal, Phytotoxicity

\section{Introduction}

As human undergoes industrialization the amount of waste discarded into the environment began to increase tremendously (Inuwa, 2004). The population of explosion and increasing level of industrialization compelled urbanization have led to environmental pollution (Filazi et al.,2003).

A mechanic village is an area of open land allocated to automobile repair workers in the vicinity of an urban centre. A typical city usually has one to three mechanic villages, in proportion to its population and activities, but some cities have more (Nwachukwu et al., 2010). The vicinity of the mechanic village is characterized with heavy vehicular activities and high production of automobile waste, which produces a resultant air, soil, surface and sub-surface water pollution.
Biological indicators have been used for many years to detect the deposition, accumulation and distribution of heavy metal pollution. During the past few decades there has been an increase in the use of higher plant leaves as biomonitors of heavy metal pollution in the terrestrial environment (Zurayk et al., 2001). Uptake and accumulation of elements in plants may follow different paths, i. e. the foliar surface and the root system. The relative importance of these routes for pollutant flux toward the leaves isn't clear on tree leaves. (Kabata-pendias et al., 1993)

Soil as a component of terrestrial ecosystems, being essential for the growth of plants is a dynamic system and subject to short term fluctuations, such as variation in moisture status, $\mathrm{pH}$ and release conditions and also undergoing gradual alterations in response to changes 
in management and environmental factors.(Abubakar et al., 2004).

The disposal of Spent Engine Oil (SEO) into gutters, water drains, open vacant plots and farms is a common practice in Nigeria especially by motor mechanics. This oil, also called spent lubricant or waste engine oil, is usually obtained after servicing and subsequently draining from automobile and generator engines (Anoliefo and Vwioko, 2001) and much of this oil is poured into the soil. There are relatively large amounts of hydrocarbons in the used oil, including the highly toxic polycyclic aromatic hydrocarbons (Wang et al., 2000). Also, most heavy metals such as $\mathrm{V}, \mathrm{Pb}, \mathrm{Al}$, Ni and $\mathrm{Fe}$ which were below detection in unused lubricating oil have been reported by Whisman et al., (1974) to give high values (ppm) in used oil. These heavy metals may be retained in soils in the form of oxides, hydroxides, carbonates, exchangeable cations, and/or bound to organic matter in the soil. Nevertheless, this is dependent on the local environmental conditions and on the kind of soil constituents present in the soilwater system. Ekundayo et al., (1989) have shown that a marked change in properties occurs in soils polluted with petroleum hydrocarbons, affecting the physical, chemical and microbiological properties of the soil. Oil pollution of soil leads to build up of essential (organic $\mathrm{C}, \mathrm{P}, \mathrm{Ca}, \mathrm{Mg}$ ) and non-essential ( $\mathrm{Mg}, \mathrm{Pb}, \mathrm{Zn}, \mathrm{Fe}, \mathrm{Co}$, $\mathrm{Cu}$ ) elements in soil and the eventual in soil and the eventual translocation in plant tissues (Vwioko et al., 2006). Although some heavy metals at low concentrations are essential micronutrients for plants, but at high concentrations they may cause metabolic disorders and growth inhibition for most of the plant species (Fernandes and Henriques, 1991). However, plants respond differently to pollutants, Anoliefo and Vwioko(1995) reported that the contamination of soil with spent engine oil caused growth retardation in plants, with the effect more adverse for tomato (Lycopersicomesculentum) than pepper (Capsicum annum L.), Maize (Zea mays L.), a major cereal in Nigeria and many African countries.

It has been the interest of the public to know whether vegetables, fruits and food crops cultivated in polluted soils are safe for human consumption especially now that the environmental quality of food production are of major concern (Chiroma et al., 2003). The understanding of the behavior of heavy metal in soilplant system seems to be particularly significant. The sources of heavy metal in plants are their growth media (air, soil, nutrients) from which heavy metals are taken up by roots or foliage. Although some heavy metals such as $\mathrm{Cu}, \mathrm{Zn}, \mathrm{Mn}$, and $\mathrm{Fe}$ are essential in plant nutrition, many heavy metals do not play any significant role in the plants physiology. Plants growing in a polluted environment can accumulate the toxic metals at high concentration causing serious risk to human health when consumed (Vousta et al., 1996; Alloway, 1990; Kabata-Pendias, 1984)

The presence of those trees in the mechanic village will be affected by the pollutant. While most plants exposed to high level of soil toxins may die off, scientist have discovered that certain plants are resistant to these toxins and even a smaller group actually thrive (Zhu and Terry; 1999). Thriving plants show a particular potential for remediation because some of them actually transport and accumulate extremely high levels of soil pollutants within their bodies. They are aptly named hyper accumulators (Akhionbare et al., 2010).

Many human diseases result from the consumption of these hyper accumulators, making study of the area crucial in the protection of human health and also essential in determining the level of bioaccumulation of heavy metal by these different species of trees in order to save the environment at large. B However, the fruits are taken by people for consumption or herbal use.

Polluted soil poses a severe problem to both health and land development. Soil lies at the confluence of many natural systems, therefore soil pollution, can be spread to other parts of the natural environment (Akhionbare et al., 2010). High concentrations of heavy metals $(\mathrm{Cu}, \mathrm{Cd}$ and $\mathrm{Pb}$ ) in fruits and vegetables have been related to high prevalence of upper gastrointestinal cancer by Turkdogan et al., 2002.

Hence the study is much concern with the determination of the effectiveness of phytoremediation of selected tree species in some part of Abeokuta, Ogun state. To also quantify the concentration of heavy metals in the soil around trees in the mechanic village and to assess the rate of uptake of heavy metals by each component of the trees in comparison to what is obtainable in a control farmland, variation in the concentration of heavy metals in the trees and between soil samples and are noted.

theoretical underpinning: The mechanic village studied is located along the Abeokuta - Ibadan expressway, Odeda local government, Ogun state, Nigeria. It covers a large span of land and serves as the major mechanic workshop for the Abeokuta metropolis and other neighboring states. The presence of cover trees such as Neem (Azadirachtaindica), cashew tree (Anacardiumoccidentale), and mango tree (Maniferaindica) is predominant in the land area.

Sample collection: Environmental quality assessment of soil is made by various methods, based on the available data and the environmental conditions prevailing in the 
locality or region of study (Nwachukwu et al., 2010). The soil samples were collected at both the Mechanic village, along Abeokuta-Ibadan expressway and COLANIM farmland at The Federal University of Agriculture, Abeokuta. Composite soil samples was collected from the base of each species of trees to be sampled, at a depth of 0-15 cm (top soil) and $15-30 \mathrm{~cm}$ (subsoil) of the soil, using a soil auger and collected in polythene bags, then transported to the Laboratory where it is air dried and sieved to $2 \mathrm{~mm}$ particle size.

Also at the sites stated above, the samples of the leaf of the trees to be analyzed which includes Neem, Cashew, and Mango tree. A composite of each tree leaf is collected by cutting from the top, middle and bottom of the trunk of the tree with the aid of pre-washed stainless knife, and further washed after each sampling with $10 \%$ nitric acid to avoid cross contamination. The bark sample was wrapped with paper, and kept in a polythene material and thereafter transported to the laboratory. Random samples are carefully chosen to reflect the areas of high mechanic activities in the mechanic village.

Soil Physical parameters analysis: 5 grams of air dried and $2 \mathrm{~mm}$ sieved soil sample was weighted into $100 \mathrm{ml}$ sampling bottles and $100 \mathrm{ml}$ of distilled water was added. The sampling bottles where then arranged on an Edmund Bühler KS-A SWIP Orbital shaker and allowed to shake for 30 minutes. The mixture is poured into distilled water rinsed beaker, then the Temperature, Electrical conductivity and $\mathrm{pH}$, where determined using HANNA combo $\mathrm{pH}$ and EC meter.

Soil digestion and heavy metal determination: Two (2) grams of air dried and $2 \mathrm{~mm}$ sieved soil was weighted of each soil sample into a BÜCHI k-424 digestion unit. $2 \mathrm{ml}$ of concentrated sulphuric acid/selenium spec solution and $4 \mathrm{ml}$ of concentrated hydrogen peroxide was dosed into each sample. The sample was allowed to digest at $300-400^{\circ} \mathrm{C}$ until content changes from black to colourless or light golden yellow in the digestion tubes. Digestion was complete when the solution became clear with appearance of white fumes (Audu and Lawal, 2005). The digest was allowed to cool to room temperature and carefully made-up to $100 \mathrm{ml}$ with deionized water in a standard flask. The digest was stored in a $100 \mathrm{ml}$ sample bottle. Heavy metals where determined by aspirating samples into a calibrated Thermo S4 Atomic Absorption spectrometer (AAS) with a digital read out system. Calibration curves were prepared separately for all the metals by running different concentrations of standard solutions. The instrument was set to zero by running the respective reagent blanks. The digested solutions were aspirated individually and atomized in an air-acetylene flame. All samples were run in triplicates and average values taken for each determination.

Leaves Analysis: One (1)g of each of the samples collected and oven dried at a temperature of $105^{\circ} \mathrm{C}$ for about 3 hrs (Majolagbe et al, 2010), was measured into BÜCHI k-424 digestion unit. $2 \mathrm{ml}$ of concentrated Sulphuric acid, $4 \mathrm{ml}$ of perchloric acid and $25 \mathrm{ml}$ of concentrated nitric acid was dosed into the sample in the digestion tube. The sample was allowed to digest at $300-400^{\circ} \mathrm{C}$ until brown fumes of nitric acid disappear and digest becomes colourless or light golden yellow. Digest was allowed to cool to room temperature and made-up to $100 \mathrm{ml}$ with deionized water in a standard flask. The digest was stored in a $100 \mathrm{ml}$ sample bottle. Heavy metals where determined by aspirating samples into a calibrated Thermo S4 Atomic Absorption spectrometer (AAS) with a digital read out system. Calibration curves were prepared separately for all the metals by running different concentrations of standard solutions. The instrument was set to zero by running the respective reagent blanks. The digested solutions were aspirated individually and atomized in an air-acetylene flame. All samples were run in triplicates and average values taken for each determination.

\section{RESULTS AND DISCUSSION}

The result obtained for EC ranges from $25 \mu \mathrm{S} / \mathrm{cm}-195$ $\mu \mathrm{S} / \mathrm{cm}$ and $70 \mu \mathrm{S} / \mathrm{cm}-276 \mu \mathrm{S} / \mathrm{cm}$ for the control farmland and mechanic village respectively while the temperature ranges for control farmland and mechanic villages ranges from $27.8^{\circ} \mathbf{C}-28.0^{\circ} \mathrm{C}$ and $27.7^{\circ} \mathbf{C}$ $28.1^{\circ} \mathrm{C}$ respectively. The $\mathrm{pH}$ of the control farmland and mechanic villages ranges from 6.47-7.67 and 6.487.79 respectively The mean and standard deviation of the result of farmland and the mechanic village as shown in Table 1 below.

Table 1: The Mean values of some selected Physicochemical Parametres

\begin{tabular}{llll}
\hline & $\operatorname{Temp}\left({ }^{\circ} \mathrm{C}\right)$ & $E C(\mu \mathrm{S} / \mathrm{cm})$ at $25^{\circ} \mathrm{C}$ & $\mathbf{p H}$ \\
\hline Control Farmaland & $28.0 \pm 0.0816$ & $95.0 \pm 68.01$ & $7.14 \pm 0.42$ \\
Mechanic Village & $27.8 \pm 0.10$ & $136.9 \pm 49.5$ & $7.17 \pm 0.42$ \\
\hline
\end{tabular}


The mean $\mathrm{pH}$ and the temperature are of the soils samples collected from both the farmland and the mechanic village was 7.14 and 7.17 respectively, which is neutral and the mean temperature of $27.9^{\circ} \mathrm{C}$ for both the farm land and the mechanic village.

The variation in the mean electrical conductivity between the farmland and the mechanic village were 95 $\mu \mathrm{S} / \mathrm{cm}$ at $25^{\circ} \mathrm{C}$ and $136.9 \mu \mathrm{S} / \mathrm{cm}$ at $25^{\circ} \mathrm{C}$ shows significant difference in their mean at 0.05 level of significant (see table 1). It indicates that the mineral salts present in the mechanic village, is higher in comparison to the average farmland, hence higher conductivity.

The mean and standard deviation of the soil heavy metal analysed for the farmland and mechanic village are presented in table 2 below. Table results indicates that there is an increase in the mean level of the concentration of cadmium, lead and copper in the soil due to the mechanic activities going on in the mechanic village.

The mean concentrations of the heavy metals in the soil of the farmland are in this order of magnitude $\mathrm{Cd}>\mathrm{Cu}>\mathrm{Pb}$, while the mean concentration of the heavy metals in the soil of the mechanic village are in the order of magnitude $\mathrm{Pb}>\mathrm{Cu}>\mathrm{Cd}$. Lead has the least concentration in the farmland, while in the mechanic village, it is the predominant heavy metal detected which also shows greater significant different at $\mathrm{p}<0.05$ concuring with the work of Lawal et. al. 2011. Also, the maximum statistical value for the concentration of lead in the soil at a point in the mechanic village, which is at $24.34 \mathrm{mg} / \mathrm{kg}$ as shown in figure 3 which indicates area of high mechanic activity. Opaluwa., et al (2012) noted that the spread of these metals over a large span of land and the continuous usage of these farmlands for growing crops could lead to bioaccumulation, hence the need for reduction in the concentration of the metals

Table 2: The Variation of Some Heavy Metals in Soil Between the Control and the Mechanic Village

\begin{tabular}{clll}
\hline & $\mathbf{C d}(\mathbf{m g} / \mathbf{k g})$ & $\mathbf{P b}(\mathbf{m g} / \mathbf{k g})$ & $\mathbf{C u}(\mathbf{m g} / \mathbf{k g})$ \\
\hline Allowable Limit & 100 & 600 & 100 \\
Farmland (Control) & 0.062 & 0.000 & 0.018 \\
Mechanic Village & 0.069 & 2.959 & 0.137 \\
\hline
\end{tabular}

Source: Field Work, 2014 and WHO (2010)

The mean and standard deviation of digested leaf farmland and mechanic village were also presented on the table 3 below

Table 3: The Variation of Some Heavy Metals in the Leaf of the Control Farmland and the Mechanic Village

\begin{tabular}{llll}
\hline & $\mathbf{C d}(\mathbf{m g} / \mathbf{k g})$ & $\mathbf{P b}(\mathbf{m g} / \mathbf{k g})$ & $\mathbf{C u}(\mathbf{m g} / \mathbf{k g})$ \\
\hline Allowable Limit & 100 & 600 & 100 \\
Farmland (Control) & $0.0250 \pm 0.0055$ & $\mathrm{~Pb} 0.0001 \pm 0.0000$ & $0.1046 \pm 0.0066$ \\
Mechanic Village & $0.0220 \pm 0.0040$ & $0.011 \pm 0.035$ & $0.1300 \pm 0.0386$ \\
\hline
\end{tabular}

Source: Field Work, 2014 and WHO (2010)

Table 4: Percentage mean concentrations uptake by trees

\begin{tabular}{llll}
\hline & Cadmium & Lead & Copper \\
\hline Neem & $19.7 \%$ & $25.2 \%$ & $58.4 \%$ \\
Mango & $23.63 \%$ & $37.5 \%$ & $87.7 \%$ \\
Cashew & $26.6 \%$ & $25.0 \%$ & $46.40 \%$ \\
\hline
\end{tabular}

From the table above it indicated that copper are easily absorbed from the soil by the all the selected tree species and that Cadmium once found in the soil is not easily phytoremediated compare to either copper or lead. It is very important to reduce the abundance of Cadmium found with the lithosphere because it toxicity is linked with reproduction problem which affects sperm and reduces birth weight. It is a potential carcinogen and seems to be a causal factor in cardiovascular diseases and hypertension. Large concentrations of $\mathrm{Cd}$ in the soil are associated with parent material (black slates) and most are manmade (burning of fossil fuels, application of fertilizers, sewage sludge, and plastic waste).Cadmium derives it toxicological properties from its chemical similarity to zinc and essential micro nutrients for plants, animals and humans. Cadmium is bio persistent and, once absorbed by an organism, remains residence for many years (over decades for humans) although it is eventually excreted. (UNEP, 2002)

It is very interesting to note from result presented on table 4 that Mango is a good phytoremediation plant species as it is very efficient in the uptake of all the 
three heavy metal under study with copper and lead mean concentration having $87.7 \%$ and $37.5 \%$ remediated from the environmental soil of the mechanic village. It is also very good that most of the copper are easily remediated because copper can be found in many kinds of food, in drinking water and in air, we also absorb eminent quantities of copper each day by eating drinking and breathing. The absorption of copper is necessary, because copper is a trace element i.e essential for human health. Although human can handle proportionally large concentration of Copper, too much of this copper can still cause eminent health problems.

It is also very disheartening that only $37.5 \%$ of the lead can be phytoremediated by the abundance of this tree indigenous tree species under investigation and more specifically Mango leaving much of it in the soil. It is dangerous because Lead poisoning is one of the most prevalent public health problems in many parts of the world. It was the first metal to be linked with failures in reproduction. It can cross the placenta easily. It also affects the brain, causing hyperactivity and deficiency in the fine motor functions, thus, it results in damage to the brain. The nervous systems of children are especially sensitive to lead leading to retardation. It is also cardiotoxic and contributes to cardiomyopathy (UNEP, 2002).

One can conclude that amongst the tree plant species under investigation, the percentage uptake efficiency are in this order of increasing magnitude Mango $>$ Neem $>$ Cashew. Although one caveat that may be established for the low uptake in respect to cashew as a phytoremediation plant is the less abundance of mechanic activities within, around and under the cashew tree and this is because of it lack of adequate leaves cover for shelter

Table 5: The Percentage Uptake of Leaf Against Bark from the Three Species Studied

\begin{tabular}{llllll}
\hline Metals & & $\begin{array}{c}\text { Ec/codex } \\
\mathrm{mg} / \mathrm{kg}\end{array}$ & $\begin{array}{c}\text { Mean conc. In } \\
\text { plant bark } \mathrm{mg} / \mathrm{kg}\end{array}$ & $\begin{array}{c}\text { Mean conc. In } \\
\text { plant bark } \mathrm{mg} / \mathrm{kg}\end{array}$ & $\begin{array}{l}\text { Percentage uptake } \\
\text { of leaf from bark }(\%)\end{array}$ \\
\hline $\mathrm{Cd}$ & $0.05-0.10$ & 0.200 & 0.042 & $\mathbf{0 . 0 2 2}$ & $\mathbf{5 9 . 5 2 \%}$ \\
$\mathrm{Cu}$ & 0.10 & 0.300 & 0.052 & $\mathbf{0 . 1 3 0}$ & $\mathbf{2 5 0 . 0 \%}$ \\
$\mathrm{Pb}$ & 0.10 & 0.300 & 0.299 & $\mathbf{0 . 0 1 1}$ & $\mathbf{3 . 6 8 \%}$ \\
\hline
\end{tabular}

From our analysis we also detected that the percentage of uptake of these heavy metals under investigation are less in the leaf compare to the bark with exception of copper which has more percentage of its uptake in the leaf than the bark and this might be because copper are also found in abundance in the air and can easily attached itself to the leaf through the air and not necessarily from the soil via the bark. The percentage of it uptake in the leaf compare to the bark are $250 \%$, $59.52 \%$ and $3.68 \%$ and of Copper Cadmium and Lead respectively (See table 5). It is also important to note that the most delicate of the three which is lead is found in restricted quantity and that the mean concentration of the of all the three heavy metals found in the leaf are within the permissible limit of the FAO/WHO and EC/CODEX standard.

Conclusion: The presence of heavy metals in the soil of mechanic village which are absorbed by the leaf via the bark has greater implication to environmental study and the general health welfare of the populace because the indigeneous tree which used as shelter are also has it economy important in fruiting which human eat directly or are refined for fruit juice. The used of these trees as phytoremediation also has importance to the well being of the environment since the plant are natural occurring or could be planted to removed these heavy metal in the soil for future agricultural used. The study also went further to ascertained the percentage contribution of these plants and concluded that mango is best suited for phytoremediation and can be used effectively to remediate almost $88 \%$ of the copper that may be found within the soil. Although it is found within the study that most of the plants are found within the permissible limit of FAO/WHO and EC/CODEX standard except for copper in some instances. The study also advocates that more plants should be study so as to compare the effectiveness of these plants in sustainable environment and people should reduce the rate at which they eat the fruits and use the leaves for herbs because bioaccumulation of this metal pollution in the soil will increase the metals in the soil and also increase by the plant uptake.

Acknowledgement: We appreciate the effort of Centre of Biotechnology Research, Federal University of Agriculture, Abeokuta, Ogun State. Nigeria for its Research Grant and analysis of the entire specimen goten from the field and also to thanks Segshi Enterprises for its financial support towards the project.

\section{REFERENCES}

Akhionbare, S., Ebe, T. and Chukwuocha, N. (2010). Heavy metal uptake by corn (Zea mays L.) grown on contaminated soil. Res.J. Agric. Biolog.Sci. 6:993-997.

Alloway B J. (1995). Heavy metals in soils.2nd ed. Chapman and Hall, Glasgow and water samples.University of Ibadan Press, Ibadan. Pp. 231 
Abubakar S. Anoliefo,G O. and Edegbai B O. (2000). Effect of Spent Engine Oil as a Soil Contaminant on the Growth of Two Egg Plant Species, Solanummelongena $L$ and solanumincanum L. J. Agric. For.Fish. 1: 21-25.

Anoliefo, G O; Vwioko, D E (1995). Effects spent lubricating oil on the growth of Capsicum annum L. and Lycopersicon esculentum Miller. Environmental Pollution, 88: 361-364.

Anoliefo, G O; Vwioko, D E (2001). Tolerance of Chromolaena odorata (L)K. and R. grown in soil contamination with spent lubrication oil. Journal of Tropical Biosciences, 1:20-24.

Audu, AA. and Lawal, AO. (2005). Variation in Metal Contents of Plants in Vegetable garden sites in Kano Metropolis. Journal of Applied Science and Environmental Management, 10(2): 105-109

Chiroma, TM. Hymoren FK. and Ebawele, RO. (2003). Heavy Metal contamination of vegetables and soils irrigated with sewage water in Yola. NJERD, Vol., 2 No.

Ekundayo, JA. Aisueni, N. and Benka-Coker, MO (1989). The Effects of drilling fluids in some waste and burrow pits in western operational areas of Shell Petroleum Development Company of Nigeria Limited, on the soil and water quality of the areas. Environmental Consultancy Service Group, Consultancy Services Unit, University of Benin, Benin City, Nigeria.

Fernandes JC, Henriques FS (1991) Biochemical, physiological andstructural effects of excess copper in plants. Bot Rev 57:247-273

Filazi, A. Baskaya, R. kun, C. and Hismiogullar, S E. (2003): Metal Concentration in Tissue of the Black Sea Fish Mugilauratus from Sinopklimari. Turkey. Human and Experimental Toxicology.22: 85-87.

Inuwa M. (2004), Analytical Assessment of some Trace Metals in soil Sodan Apple (calotropisprocera).Around the major industrial Areas of North West zon.Unpublished.M.Sc

Kabata, P A. and Pendias, H. (1984). Trace Elements in the soil and plants CRC Press, Boca Raton FL.

Kabata-Pendias A., Motowicka-Terelak T., Piotrowska M., Terelak H., Witek T.(1993) Ocena stopnia zanieczyszczenia gleb i roślin metalami ciężkimi i siarką. IUNG Puławy, Seria P (53).

Majolagbe, AO; Paramole, AA; Majolagbe, HO; Oyewole, O; Sowemimo MO (2010). Concentration of heavy metals in tree barks as indicator of atmospheric pollution in Oyo Town, Southwest, Nigeria, Scholars Research Library rchives of Applied Science Research, 2010, 2 (1):170178.
Nwachukwu, M A.,Feng,H. and Alinnor, J. (2010) Assessment of heavy metal pollution in soil and their implications within and around mechanic villages. Int. $J$. Environ. Sci. Tech., 7 (2), 347-358.

Opaluwa, OD; Aremu, MO; Ogbo, LO; Abiola, KA; Odiba, IE; Abubakar, MM; Nweze, NO (2012). Heavy metal concentrations in soils, plant leaves and crops grown around dump sites in Lafia Metropolis, Nasarawa State, Nigeria. Advances in Applied Science Research, 2012, 3 (2):780-784.

Turkdogan, M K., Kilicel, F., Kara,K. andTuncer I. (2002) Heavy metals in soil, vegetables and fruits in the endemic upper gastrointestinal cancer region of Turkey. Environmental Toxicology and Pharmacology 13: 175-179.

UNEP (2002) Central American and Carribean Regional Report.Regionally based on the Assessment of persistant Toxic Substance.Genovia Switzerland.

Vousta, D. Grimanins A. and Sammara C. (1996). Trace elements in vegetable grown in an industrial area in relation to soil and air particulate matter. Environ. Pollut.94(3): 325 - 335

Vwioko, D E., Anoliefo, G O. and Fashemi, S D. (2006). Metal concentration in plant tissues of Ricinuscommunis L (Castor oil) grown in soil contaminated with spent lubricating soil. J. Applied Environ. Management 10 (3):127 - 134 .

Wang, J; Jiq, C R; Wong, C K; Wong, P K (2000). Characterisation of polycyclic aromatic hydrocarbons created in lubricating oils. Water, Air and Soil Pollution, 120: $381-396$

Whisman, M L.,Goetzinger, J W. and Cotton, F O. (1974). Waste lubricating oil research. In: An Investigation of Several Re-fining Methods. Bureau of mines, Bartlesville, Energy Research Center

World Health Organization Guildlines for heavy metal WHO Geneva

Zhu,Y L.and Terry,N. (1999)."Phytoaccumulation of Trace Elements by Wetland Plants", Journal onEnvironmental Quality, 28: 339-344.

Zurayk R., Sukkariah, B. and Baalbaki, R. (2001) Common Hydrophytes as Bioindicators of Nickel, Chromium and Cadmium Pollution.Water, Air and Soil Pollut.127, 373, 